\title{
INTEREST RATES, RISK, AND IMPERFECT MARKETS: PUZZLES AND POLICIES
}

\author{
JOSEPH E. STIGLITZ \\ The World Bank
}

Traditional theory emphasizes the key role that monetary policy can play through the manipulation of interest rates. But there are several puzzles that cannot be reconciled with standard models. These include: the apparent constancy in interest rates over extended periods, and changes at other times which appear unrelated to changes in technology and demography; the cyclical pattern of movements in real interest rates; the impact of nominal not real interest-rate changes on real variables; and the cyclical pattern of movements in interest-rate spreads. This paper reaches beyond the standard competitive equilibrium, perfect information, model of credit markets towards imperfect information models, particularly those that focus on the determinants of bank behaviour. Of the standard models, the money demand model is most deficient in understanding these puzzles. The loanable funds theory and a generalized version of real productivity theory can be reconciled with imperfect information, and markets and the consequent credit and equity rationing regimes help to explain the puzzles. Specifically, banks may be insensitive to changes in monetary stance owing to risk aversion. There are strong policy implications; it is argued, for instance, that in East Asia raising interest rates exacerbated economic decline and, rather than contributing to exchange-rate stability, may have induced capital flight as default risk increased, lowering risk-adjusted expected returns.

\section{INTRODUCTION}

Modern economic theory has stressed the key role that real interest rates play in economic behaviour: real interest rates affect investment, which, in turn, affects the aggregate level of economic activity. Monetary policy is given a central role in controlling the level of economic activity through its role in controlling interest rates. Monetary authorities are hypothesized to change nominal interest rates in response to a change in expectations concerning inflation so

\footnotetext{
${ }^{1}$ This paper extends Stiglitz (1995). The author is Chief Economist and Senior Vice President at the World Bank, on leave from Stanford University. He is indebted to Maya Tudor and Nadia Roumani for helpful assistance. The views expressed are solely those of the author, and not necessarily those of any institution with which he is or has been affiliated.
} 
that the real interest rate adjusts in the desired way. $^{2}$

In spite of the central role the interest rate plays, there are several long-standing puzzles. First, how can we reconcile observed movements in real interest rates with shifts in the demand and supply curve for funds? Why is there a seeming constancy over long periods of time while, in some periods, there are also dramatic changes in real interest rates seemingly unrelated to, say, large changes in technology, underlying preferences or demography? How can we explain the cyclical movement of real interest rates? Second, why is it that empirical studies often seem to show that nominal interest rates, not just (or in some cases, even) real interest rates matter? Third, how do we explain the relationship among returns, e.g. the equity premium or cyclical movements in interest rate spreads?

This paper argues that to find the answer to these puzzles, we must move away from the standard competitive equilibrium and perfect information model of credit markets towards imperfect information (and in some cases, imperfect competition) models, particularly those that centre around banks and the determinants of their behaviour. Moreover, I argue that this perspective has strong policy implications; that using the wrong model not only may produce the wrong results, but results that are counterproductive. The disastrous course of policies pursued in East Asia in response to the 1997 crisis illustrates such dangers.

Standard economic theory has employed three distinct models of interest-rate determination: the money demand model, the loanable funds model, and the neoclassical 'real productivity' theory. After quickly disposing of the money demand model, I show how the imperfect information/imperfect markets approach can be used to reconcile the loanable funds and (a generalized version) of the real productivity theory.

\section{THE COMPETITIVE EQUILIBRIUM MODEL AND THE EMPIRICAL PUZZLES}

The deficiencies in the money demand model, which has been the centre of attention at least since Keynes (see Keynes, 1936), are increasingly being recognized. In that model, the demand for money depends on the level of (money) national income and the interest rate, which represents the opportunity cost of holding money. But today, most money is interest bearing (see, for example, Stiglitz, 1988b). Indeed, on large accounts, the interest rate is little different from that on Treasury Bills (T-bills). (The spread is determined basically by technology, by the relatively small transactions costs, and has little to do with cyclical concerns.) Hence, the opportunity cost of holding an interest-bearing money account (such as a cash management account) is negligible. To be sure, there is an opportunity cost for holding currency, but few have advocated a currency theory of interest-rate determination, for obvious reasons. Second, money is not needed for most transactions; credit (including credit cards) can be used-and increasingly is being used-instead. Third, most transactions are in fact not income-generating, but are exchanges of assets. Were there a stable relationship between these asset exchanges and income-generating transactions, it would make little difference; but there is no reason to believe that the relationship between the two is stable, especially over the business cycle. ${ }^{3}$

In the 1930s, there was a strong competing theory, the loanable funds theory, advocated, for example, by Robertson (1936). In that model, the interest rate is determined as the intersection of a downwardsloping demand for funds and an upward-sloping supply curve of funds (Figure 1). In accordance with standard economic precepts, both depend on real interest rates: there is no money illusion. As the economy moves into a recession, the demand curve (derived from the demand for investment goods)

\footnotetext{
${ }^{2}$ Matters are considerably more complicated than this sentence might suggest. What presumably matters for investment are longterm interest rates (and the price of equity); the actions of monetary authorities seem most directly to relate to short-term interest rates. Long-term interest rates are related to expectations of short-term interest rates over an extended period of time, and it is not obvious how actions taken by the monetary authority today would have marked effects on these long-term expectations, and therefore on the long-term interest rate. This suggests, as we argue, that monetary policy may exercise its effects not so much through intertemporal price effects as through cash flow and credit availability effects.

${ }^{3}$ The money demand model determines the nominal interest rate; a separate equation (e.g. a version of the Phillips curve) is required to determine the rate of inflation, and the two together determine the real interest rate.
} 


\section{Figure 1}

\section{Loanable Funds Theory of Interest Rate Determination}

The interest rate is determined at the intersection of the demand and supply curves for loanable funds (Panel A). The demand curve is largely determined by the return to investment. Panel B shows how the curves move as the economy goes into a recession. The demand curve shifts down (and to the left), and the supply also shifts to the left. With a close to horizontal demand curve, the former effect dominates, and interest rates fall, though even with the fall of interest rates, the equilibrium level of investment falls.

Panel A

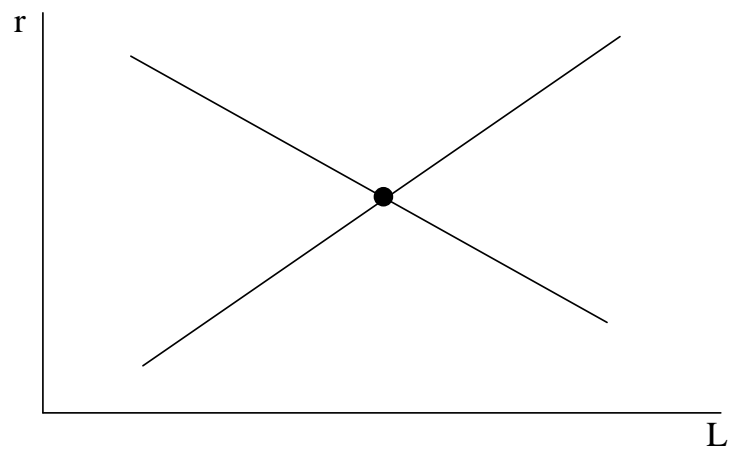

Panel B

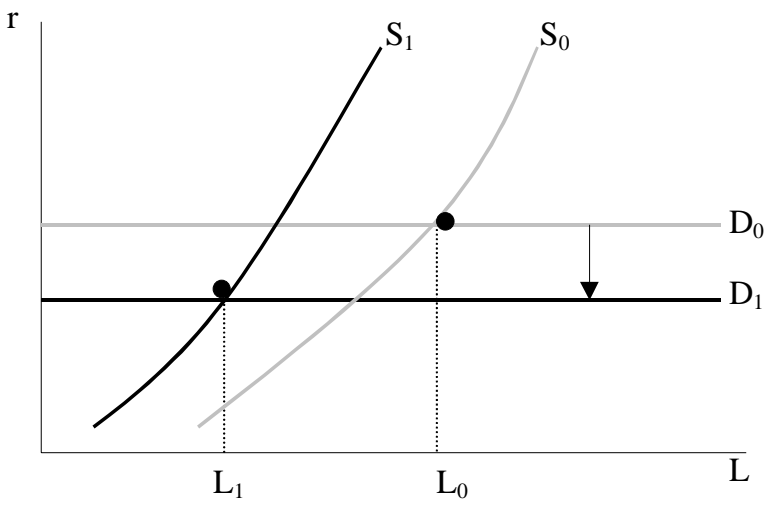

shifts markedly to the left, while the supply of funds (from savings) also shifts to the left; but the latter shifts in proportion to the decline in GNP, while the former shifts more (investment is typically the most volatile component of aggregate demand). Hence, real interest rates should fall, moving in a countercyclical manner. Monetary policy-loosening monetary policy in a recession in order to stimulate the economy-reinforces these movements, leading to a further decline in real interest rates.

The third theory focuses on the real side of the economy. The real interest rate (ignoring risk for the moment) should be equal to the marginal productiv- ity of capital. The marginal productivity of capital can be read off the production function. In the short run, the capital stock is fixed. As employment (hours worked) increases, the marginal productivity of capital increases. Hence, the real interest rate should increase in a boom, and should decrease in a recession: real interest rates should again move in a markedly countercyclical way (Figure 2 ). The magnitude of the effect can be seen by using a CobbDouglas production function. ${ }^{4}$

Writing

$$
Q=A K^{\alpha} L^{(1-\alpha)}
$$

\footnotetext{
${ }^{4}$ The discussion of the following paragraphs is taken directly from Stiglitz (1995).
} 


\section{Figure 2 \\ Real Marginal Productivity Theory}

The real interest rate should be equal to the marginal return to capital. In the short run, with the stock of capital fixed, as employment increases, the marginal productivity should increase. Hence, the real interest rate should decrease as the economy goes into a recession and employment decreases.

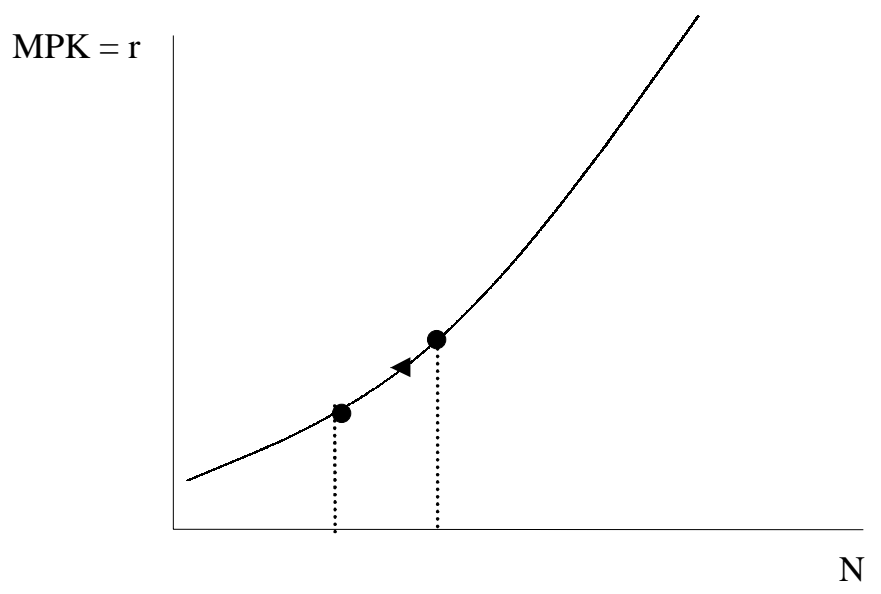

where $Q=$ output, $K=$ capital, and $L=$ labour, we obtain, under the hypothesis that the real interest rate, $r$, is equal to the marginal product of capital

$$
r=A \alpha K^{(\alpha-1)} L^{(1-\alpha)}
$$

so that, assuming that the form of the production function and the parameter $\alpha$ remain unchanged,

$$
d \ln r=d \ln A+(1-\alpha)(d \ln L-d \ln K) .
$$

Let $P$ denote average labour productivity, $Q / L$; then

$$
d \ln P=d \ln A+\alpha(d \ln K-d \ln L) .
$$

Substituting, we obtain

$$
d \ln r=d \ln P+(d \ln L-d \ln K) .
$$

As the economy comes out of a recession, by Okun's law, output increases 3 per cent for each 1 per cent increase in labour. Consider a recession with a 5 per cent trough-to-peak change in employment. For our short-period analysis, changes in capital can be ignored. Then, a 5 per cent increase in employment should increase the real return to capital (the real interest rate) by 15 per cent; by contrast, as the economy emerged from the Great Depression and from the recession of the early 1980s, real interest rates actually fell.
These results would be strengthened if we had assumed an elasticity of substitution of less than unity (as most of the microeconomic evidence suggests). The lower elasticity of substitution means that the wage-rental ratio should fall more dramatically as the labour-capital ratio rises.

We now need to reconcile these two theories with each other, and with empirical data. If we could ignore risk, reconciling the two theories would be simple enough. In the short run, we can take the capital stock and employment as fixed, and additions to capital as being relatively small compared to the stock. Investors will want to invest so long as the interest rate charged is less than the return to capital. Hence, the demand for loanable funds is close to a horizontal curve. (There is also some demand for consumption purposes, which is presumably downward sloping; but the consumption demand is small compared to the investment demand.) Hence, to a first approximation, regardless of the supply curve of funds, the equilibrium interest rate is (approximately) equal to the marginal productivity of capital. As the economy goes into a recession, then (continuing to ignore risk), the marginal productivity of capital falls, and the demand curve for loanable funds shifts down. The real interest rate falls. If real capital becomes riskier relative to T-bills (a plausible assumption, to which I shall return later), then the demand curve for 
Figure 3

Movements in the Real Interest Rates

Both long-term movements in the real interest rate and movements over the business cycle are hard to reconcile with simple versions of either the loanable funds theory or the real marginal productivity theory.

United States

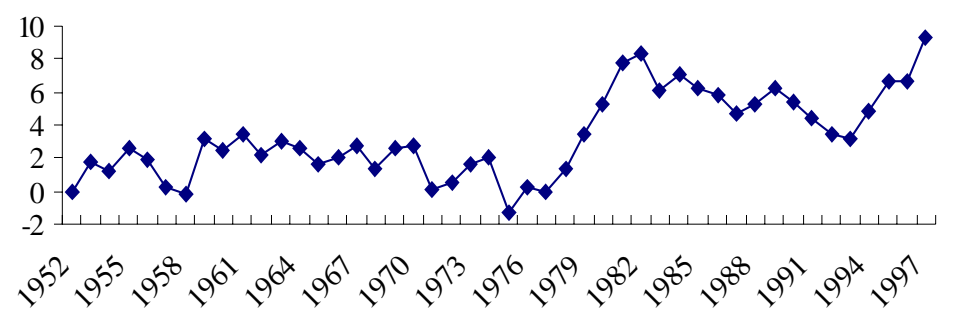

United Kingdom

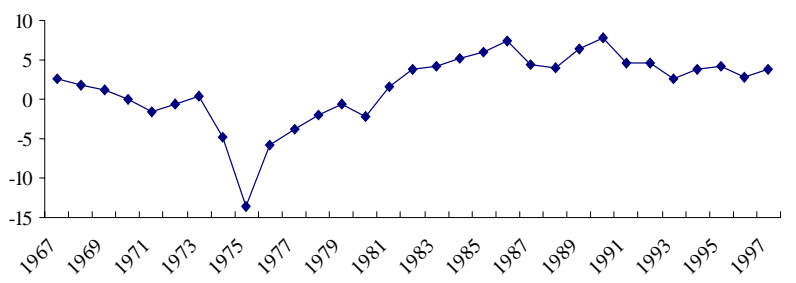

India

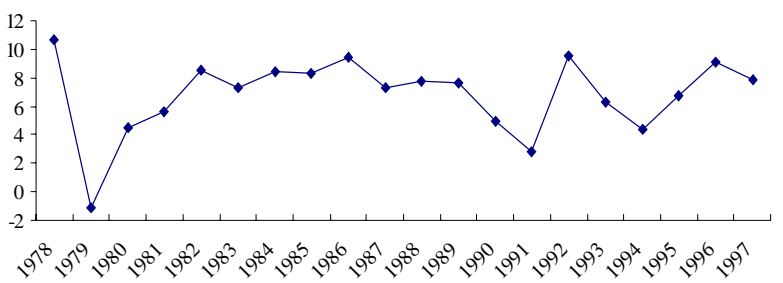

loanable funds shifts down even more, reinforcing the countercyclical effects.

In my earlier paper (Stiglitz, 1995), I pointed out the difficulties of reconciling the results with the real productivity theory, and, since the two theories seem to give parallel results, by implication with the loanable funds theory. Figure 3 shows the movement of real interest rates in the United States and several other countries. None of them exhibits the strong cyclical pattern predicted by the theory. The real productivity theory also predicts smooth changes in the real interest rate as the productivity and the labour capital ratio change. It would seem a fluke that, for instance, for nearly 20 years, between 1952 and 1969, the two just offset each other, so that real
France

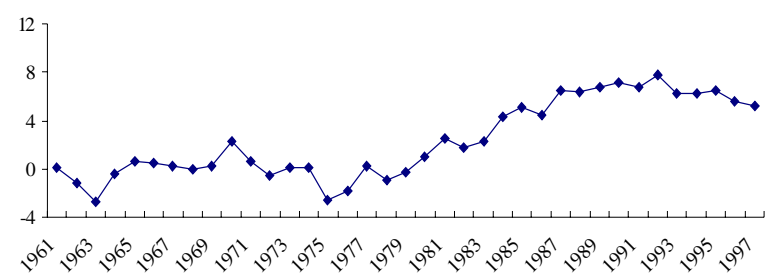

Korea

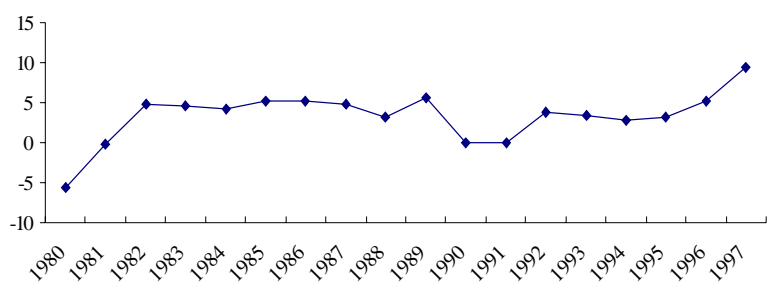

interest rates fluctuated between 1 and 3 per cent; then suddenly the marginal productivity of capital plunged, even becoming negative. Just as suddenly however, it soared to high levels not seen in a long time. Other countries exhibit similarly anomalous movements.

These numbers, however, are real interest rates on T-bills. The marginal productivity theory focuses on the return to capital. There are important differences in risk between the two assets. In real terms, neither asset is certain. While the risk of default on a T-bill is negligible, the rate of inflation is uncertain, so that there is uncertainty about the real return. By contrast, with physical capital there is both productivity risk (what will be the return to capital) and risk 
associated with the relative price of capital goods and consumption goods. ${ }^{5}$ Still, it seems implausible that changes in perceptions of the differential risk between the two assets, and in risk aversion, can reconcile the theories with the apparent movements in real interest rates.

Indeed, as I have noted, the return to equity (which should be more directly related to the real marginal productivity of capital) and its relationship to the return to debt, represents a puzzle itself. Some have observed that it is hard to reconcile the higher average return (the equity premium) with the higher variance of equities and with reasonable parameters for risk aversion, but the puzzle is deeper than that. For longer holder periods, the return to equities stochastically dominates that on debt, so that all individuals with long enough holding time horizons should hold only equities-but they do not (see MaCurdy and Shoven, 1992a,b,c). ${ }^{6}$

Before leaving the discussion of these puzzles, let me say a word about the 'spread' puzzle. Standard monetary theory focuses on the T-bill interest rate; but economic activity depends on the interest rate that borrowers (investors) must pay. The presumption of the standard theory has been that the two closely track each other, adjusting for risk. The spread between the two, however, often moves in strange ways. For instance, in the 1991 recession, the T-bill rate came down slowly, to between 3 and 4 per cent while credit card rates remained at 16 19 per cent. It seems implausible that the 'risk adjustment' just happened to change by the amount that the interest rates fell. Movements in other interest rates (e.g. prime rates) exhibit similarly anomalous behaviour (though admittedly not as striking).

\section{THE IMPERFECT INFORMATION/ IMPERFECT CAPITAL MARKET MODELS}

The imperfect information/imperfect capital market models provide at least a framework for reconciling the observed patterns of interest-rate movements with economic theory. There are three underlying ideas:

(a) Because of the probability of bankruptcy (default), expected returns on a loan are lower than 'promised' returns; the probability of bankruptcy may depend on the interest rate charged, so that beyond a point, increases in the interest rate charged actually lead to lower expected returns (see Figure 4). As a result, there may be credit rationing (Stiglitz and Weiss, 1981; Jaffee and Stiglitz, 1990).

(b) Equity markets are imperfect (again because of imperfections of information), so that firms cannot fully divest themselves of the risks they face; they must borrow. ${ }^{7}$ There is a probability that they may not be able to meet their debt obligations - that they will go bankrupt. Because the costs of bankruptcy are high, firms act in a risk-averse manner. ${ }^{8}$ How risk aversely they behave depends on their net worth. When their net worth decreases, their willingness (and ability) to invest, to hire labour, to hold inventories, even to produce, decreases (see

\footnotetext{
${ }^{5}$ In addition, individuals do not buy a diversified portfolio of ' $K$ ', of the capital stock, but rather equities, which are claims on firms, which have certain outstanding debt obligations. If the Modigliani-Miller theorem were correct, then, of course, the capital structure of the firm - the nature and amount of these claims - would make no difference. But the conditions under which the Modigliani-Miller theorem is correct are highly restricted and are not satisfied in practice (see Modigliani and Miller, 1958; Stiglitz, 1974); these limitations play a large role in the discussion that follows.

${ }^{6}$ This is, of course, not the only puzzle relating to the behaviour of stock-market prices. A series of articles in the Journal of Economic Perspectives in the late 1980s and early 1990s documents a variety of capital market anomalies, and shows how the various explanations put forward do not seem to go far in explaining them. Other anomalies relate to the fact that standard theory suggests that the only part of risk that should matter in valuing a firm — and that managers should pay attention to - is covariance with the market; but this does not seem to be true (Stiglitz, 1989). Moreover, there is a variety of aspects of firm and market behaviour that seem inconsistent with firms maximizing stock-market value; the anomalous behaviour is especially apparent in how firms respond to taxes (see Stiglitz, 1973, 1981, 1982a, 1983b).

7 There is a variety of models explaining the imperfections of equity markets, based on models of adverse selection, moral hazard, costly and imperfect contract enforcement, and state-verifiability. See Myers and Majluf (1994), Bernanke and Gertler (1989), Greenwald et al. (1984), Stiglitz (1982a,b, 1988a,b, 1992). For empirical evidence in support of some of these hypotheses, see Asquith and Mullins $(1986 a, b)$.

${ }^{8}$ Unless their debt is so high that they 'gamble on resurrection' (Kane, 1989). Agency problems may also give rise to risk-averse behaviour on the part of firms; see Greenwald and Stiglitz (1990b).
} 


\section{Figure 4 \\ Dependence of Expected Return on Interest Rate Charged}

Because, as the interest rate charged increases, the probability of default increases (either because of adverse selection or moral-hazard effects), the expected return increases less than in proportion to the increase in the interest rate charged, and above a certain point, may actually decrease.

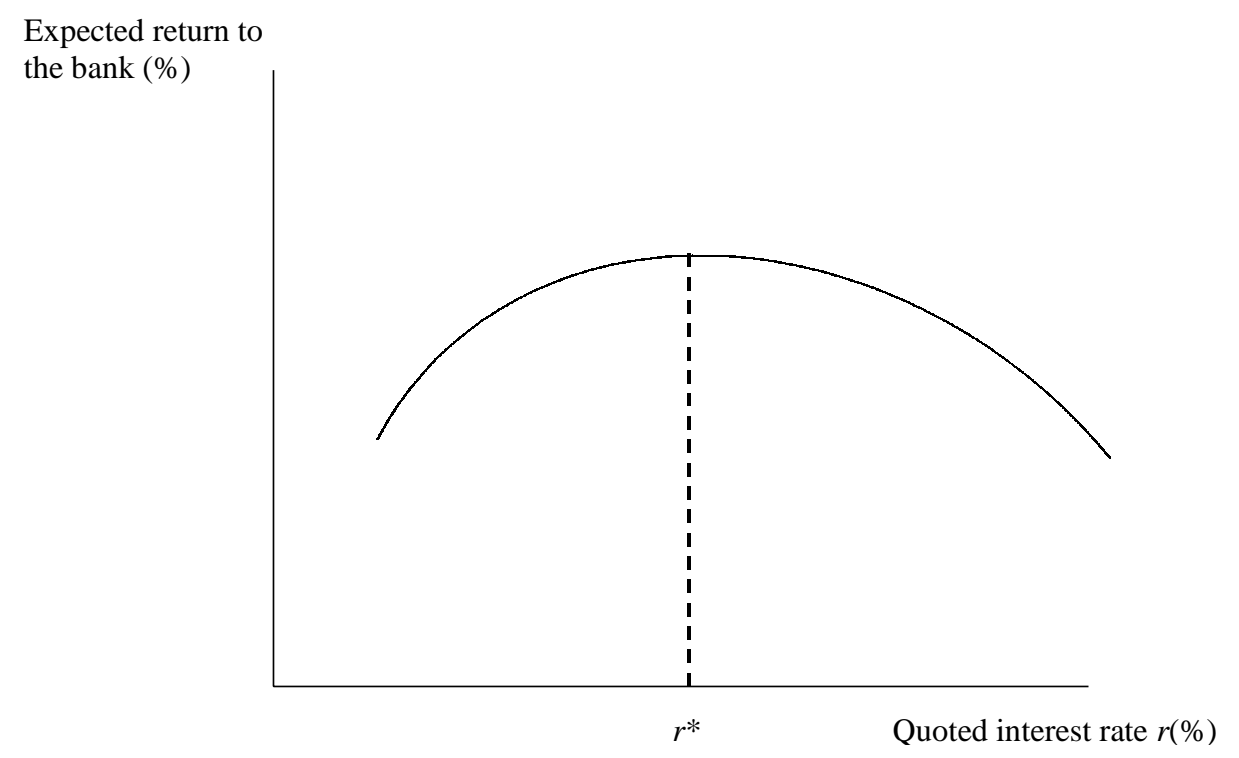

Greenwald and Stiglitz, 1987,1993,1995). (Firms may be both equity and credit constrainedsee Hellman and Stiglitz (2000) — in which case their investment is limited to their own cash. $)^{9}$ Increases in the interest rate represent a transfer of wealth from debtors to creditors, thereby eroding firm net worth. (The imperfections in equity markets imply that the firm cannot easily undo the damage by returning to the market to raise new equity. $)^{10}$ These effects are particularly significant when the increase in interest rates is unanticipated; for then the firm is likely to have a higher level of indebtedness than it would have had had it known what interest rates were going to be. And given the higher level of indebtedness, the 'cost' of the increase in interest rates is greater. ${ }^{11}$

(c) Banks can be viewed as 'firms' that are engaged in the lending/certification business. Like other firms, they are equity constrained, and act in a risk-averse manner as a result (see Greenwald and Stiglitz, 1990a, 1991a). Changes in their net worth (e.g. as a result of defaults) and/ or their risk perceptions alter their ability and willingness to lend. Increases in interest rates, while they may increase the returns banks receive, also increase its cost of capital. The dominant effect of large, unanticipated increases in interest rates is thus induced bankruptcies and an increase in non-performing loans.

The first observation means that, in the creditrationing regime, interest rates charged are determined by factors other than demand and supply for funds (or the marginal productivity of capital). Credit rationing occurs when the noncredit-rationed interest rate is above the rate at which the expected return is maximized. What matters for the latter is not the mean marginal

${ }^{9}$ A large number of studies have recently verified the importance of these cash-flow and balance-sheet effects; see, for example, Devereux and Schiantarelli (1990), Fazzari et al. (1988), Galeotti et al. (1990), Hoshi et al. (1988, 1991), Hubbard and Kashyap (1989), Gilchrist (1989), and Calomiris et al. (1986, 1987).

${ }^{10}$ Mayer (1990) documents the relatively small role that new equity issues play in financing investment.

${ }^{11}$ The model can help explain why nominal, rather than just real, interest rates matter, in several ways. First, while real interest rates matter ex ante, the 'surprise' - the nominal interest rate ex post - matters as well, since that has effects on the liquidity and balance sheet of the firm. Moreover, with high levels of inflation the firm is, in effect, repaying a large fraction of any loan every year; all medium-term loans become, in effect, short-term; the lack of long-term credit in turn has adverse effects on the firm. To be sure, lenders could design contracts, commitments to relend in real terms; but such contracts do not seem common. 
productivity of the economy as a whole, but rather the financial position of each firm. As the economy goes into recession, the market-clearing interest rate may fall below the interest rate at which expected returns are maximized, which implies that the interest rate may fail to fall-and could even rise-as the economy goes into a recession.

While the interest rate charged is that which maximizes the expected return to the lender, the interest rate paid to depositors, with competitive banking, is equal to the maximized expected return on the money deposited; this is likely to fall as the economy goes into a recession. Thus, while this theory can explain seemingly anomalous aspects of movements in lending rates of the business cycle, it does less well in explaining deposit rates. On the other hand, secular changes in technology, in the costs of monitoring and the economy's information structure, may affect the relationship between the interest rate charged and expected returns, ${ }^{12}$ so that the theory has no clear predictions concerning the relationships between lending rates, deposit rates, and mean marginal returns on capital. ${ }^{13}$

A slight variant of the model explains the possibility of rigidity of lending rates (see Rodriguez et al., 1992). The mix of borrowers facing any lender depends on the interest rate charged by other lenders. Assume for a moment that all lenders are symmetric (i.e. face an identical distribution of borrowers). The heavy curve (labelled RR) in Figure 5, Panel A, shows the expected return if they all charge the same interest rate; the light curve (labelled rr) shows the expected return to any single lender, if he or she varies the interest rate from that charged by all others. ${ }^{14}$ Because as any single firm raises its interest rate, it loses some of its best risks, the rr curve is flatter than the RR curve. If the lenders cooperated, they would all choose the interest rate $r^{*}$ at which expected returns were maximized. But the Nash equilibrium without coordination is at $r_{c}$, where each firm maximizes its own return, given the interest rate charged by all others.

Now we need to examine an equilibrium in contracts, where lenders decide both on an interest rate charged, and whether to match decreases in interest rates charged by rivals (the downward matching clause) or match increases in interest rates charged by rivals (the upward matching clause). Lenders want to discourage rivals from undercutting them, and the downward matching clause does this, by, in effect, ensuring that they get no adverse selection gain from doing so. On the other hand, they have no incentive to discourage rivals from raising interest rates, since such increases in interest rates confer on them a positive externality, i.e. a positive adverse selection effect. The equilibrium in contracts will thus entails all firms having a downward matching clause, but not an upward matching clause. We now consider what this implies for the nature of a symmetric equilibrium (which must lie along RR). Assume that there were an equilibrium, $E_{1}$, at an interest rate below $r_{c}$ (Panel B in Figure 5). Then, as depicted, it would pay any lender to increase the interest rate charged - even if rivals did not match. Hence, $E_{1}$ cannot be an equilibrium. But now consider a possible equilibrium at $E_{2}$, at an interest rate between $r_{c}$ and $r^{*}$ (Panel $\mathrm{C}$ in Figure 5). The modified rr curve now coincides with the RR curve to the left of $E_{2}$, but with the old rr curve to the right. Thus, $E_{2}$ is an equilibrium. In short, any interest rate between $r_{c}$ and $r^{*}$ is an equilibrium.

There is what is sometimes called a 'convention' equilibrium. Any interest rate-any convention(within a range) can be sustained.

\footnotetext{
${ }^{12}$ A key variable is the probability of default, which in turn depends on the leverage as well as the size of shocks facing firms within the economy; but leverage is itself an endogenous variable. As the size of shocks decreases, firms will undertake greater leverage, so that the net change in the probability of bankruptcy may change relatively little, suggesting that the changes in the discrepancy between expected returns and interest rate charged may be less than changes in the underlying structure of the economy. (These issues can be analysed using the kind of model presented in Greenwald and Stiglitz (1993).)

${ }^{13}$ One might argue that, over time, the economy becomes informationally more efficient and better at risk diversification, so that the gap between the maximized expected return on credit contracts and the mean marginal return should decrease; but while the economy might get better in processing information and diversifying risks, the magnitude of the information and risk problems can clearly change over time, overwhelming the improvements in the economy's capacities. Thus, it seems difficult to make any generalization about secular trends.

${ }^{14}$ The analogy to Chamberlain's model of monopolistic competition (Chamberlain, 1933), with his DD demand curve (where all firms change the price together) and his dd demand curve, where a single firm changes its price, given the price charged by all other firms, should be clear.
} 
Figure 5

\section{Interest-rate Determination with Many Lenders and Adverse Selection}

When there are many lenders, the expected returns to each lender depend on the interest rate charged by all lenders. If they coordinate interest-rate changes, and they all face symmetric economic environments, then the equilibrium interest rate charged will be $r^{*}$, but if they do not coordinate, then the equilibrium interest rate charged will be $r_{c}$. If lenders have downward matching clauses, but not upward matching clauses, then any interest rate between $r^{*}$ and $r_{c}$ can be an equilibrium.

Panel A

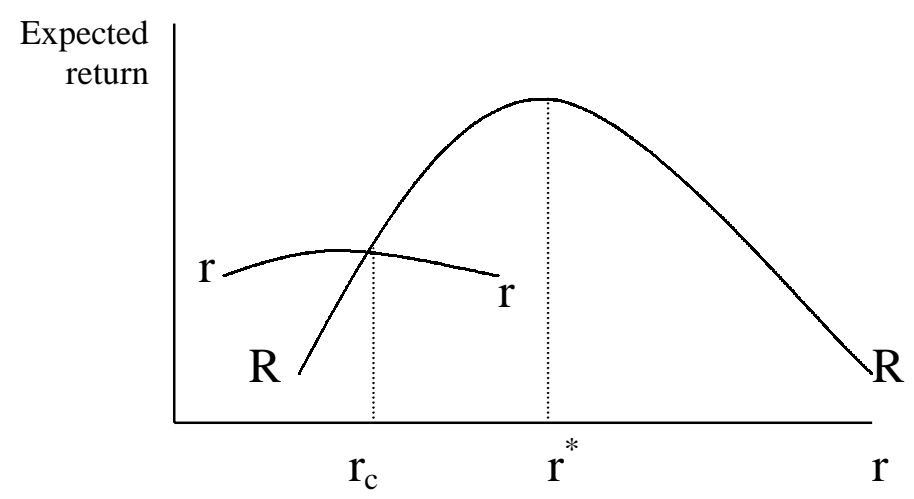

Panel B

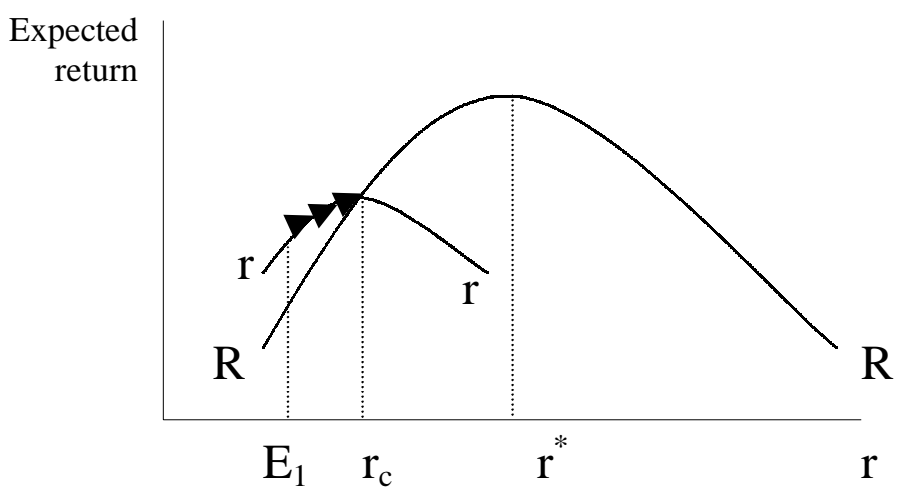

Panel C

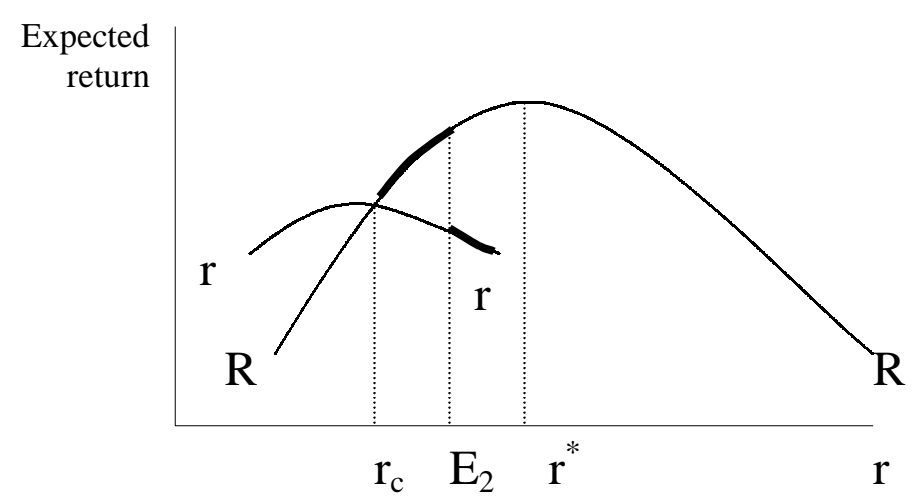

There also can be conventions about changes in the interest rate charged. So far, we have assumed that all lenders are symmetrically identical. Within the same framework, we can think of different lenders as facing slightly different circumstances (say costs of funds may be a random variable; symmetry ex ante may be maintained by assuming that they all are drawn from the same distribution). If there is a shock which changes the returns curve facing a single lender, the others may not want to respond; but if there is a shock which changes the returns curve facing all the lenders in the same way, they may want to respond in a coordinated way. Changes in the discount rate charged by the Central Bank 
may be an example of a 'shock' which affects all lenders, in roughly similar ways, so that they may want a coordinated response. If they have, in effect, 'matching clauses' which say that they will match any increases in interest rates induced by an increase in the discount rate (but if rivals fail to increase the interest rate, they will too), then there will be a coordinated response which eliminates the incentive for any lender to try to take advantage of the others through an adverse-selection effect. (Typically, there are multiple convention equilibria. If all creditors believe that all other creditors are going to leave interest rates unchanged in response to a lowering of the T-bill rate, then that is an equilibrium. If they believe that all other creditors are going to lower interest rates in response to a lowering of the T-bill rate, then that too is an equilibrium.) In a sense, the problem with these models is that they are too 'rich'; that is, they argue that factors other than the average marginal productivity of capital determine the real interest rate, but they do not give very clear predictions.

The equity-constrained models, on the other hand, can be used directly to analyse shifts in the demand and supply for loanable funds, and to yield somewhat clearer predictions. Recall the earlier discussion in which the equilibrium interest rate was basically determined by the demand curve for loanable funds, so that (ignoring risk), as the economy goes into a recession, the real interest rate falls. Once the risk-averse behaviour of firms and banks is taken into account, the demand curve for funds is downward sloping (the demand for funds for investment and working capital depends on the interest rate they have to pay); and as the economy goes into a recession, the demand curve shifts markedly to the left, as firms become more risk averse. But at the same time, banks' willingness to lend also decreases. The supply curve also shifts to the left. It may shift to the left more or less than the demand for funds. Particularly in severe recessions, as bankruptcies increase and the net worth of banks is eroded, the leftward shift of banks is even greater than that of firms, so that the equilibrium interest rate actually increases as the economy goes into a recession (Figure 6, where $r$ represents the constraints-equivalent interest rate).
If the increase in real interest rates is large enough, the economy may switch into a credit-rationing regime, as illustrated in Figure 7. Further leftward shifts in the loanable funds curve thus have no further effects on the interest rate charged, but do have large negative effects on investment and production, as credit availability is curtailed. The model makes the important point that tightness of monetary policy, in this context, may not be well gauged by looking at the interest rate charged.

\section{ECONOMIC POLICY}

The model provides a framework for thinking about monetary policy which is markedly different from the standard IS-LM model-or the neoclassical model, for that matter. The central bank can be thought of as operating on the banking system to shift the supply curve of funds to the right, lowering interest rates and increasing investment, thus stimulating aggregate demand. Consider, for instance, the impact of lowering the discount rate, which lowers the rate at which banks can borrow funds from the central bank (or the effective risk they face in falling short of reserve requirements). ${ }^{15}$ Given the lower cost of funds, banks should, at any market interest rate, be willing to lend more. But banks may exhibit a low elasticity of response: a large lowering of the discount rate may have little effect on the equilibrium lending rate (Panel A, Figure 8). Even if the loanable funds supply curve shifts more markedly, if there is credit rationing, the interest rate charged may not change much (Panel B). ${ }^{16}$ And even if the interest rate charged is lowered significantly, it may have little effect on the equilibrium level of lending (Panel C).

There may be several reasons for the lack of responsiveness of lenders. Banks may be very risk averse, so that they are unwilling to extend their risk exposure much, even if the cost of capital is lower. Or the returns (including perceived risks) on alternative investments, such as long-term government bonds, may be such that banks simply put any additional funds they have available into government bonds, rather than making more funds available for lending. Such was the case, for instance, in

\footnotetext{
${ }^{15}$ Similar results hold in the case of other actions by monetary authorities, e.g. changing the reserve requirement.

${ }^{16}$ But even though interest rates have not changed, if the supply curve shifts, the amount of lending —and accordingly, the level of economic activity—may increase markedly.
} 
Figure 6

\section{Generalized Loanable Funds Theory}

The equity constraints facing firms imply that their demand for funds (both for working capital and investment) may be sharply decreasing with the interest rate. As the economy goes into a recession, firms' net worth and cash flows are adversely affected, shifting the demand curve for funds to the left. But banks, the major suppliers of funds, also become more reluctant to lend, so that the supply curve also shifts to the left. The real interest charged may actually increase.

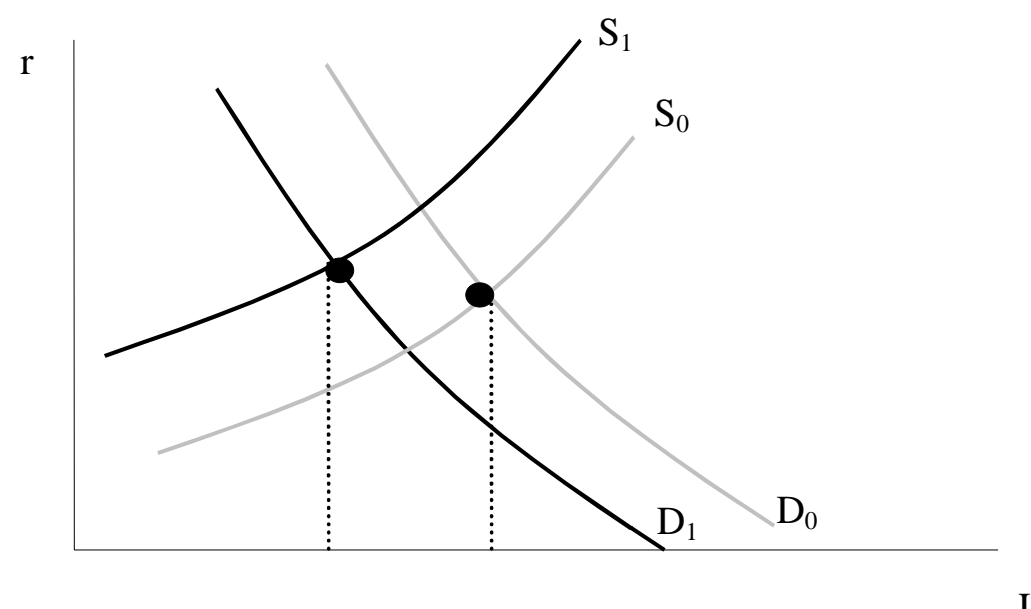

Figure 7

Generalized Loanable Funds Theory-With Credit Rationing

It is possible, however, that as the economy goes into a recession and the supply of loanable funds curve shifts markedly to the left, the interest rate charged may not rise commensurately. It pays lenders to limit the interest rate charged and to impose credit rationing.

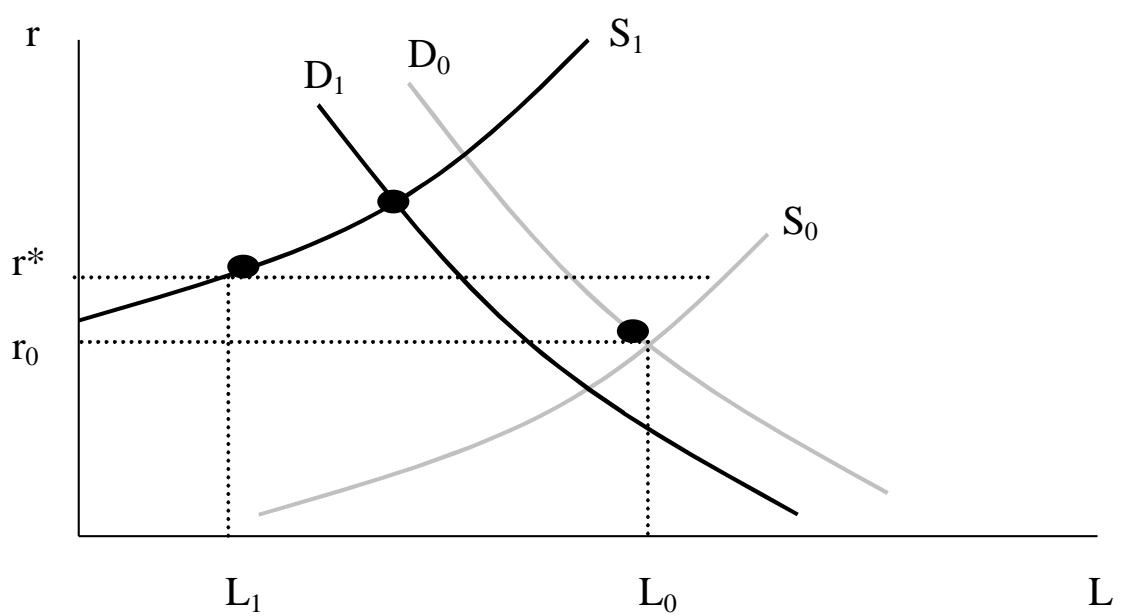

the United States as it went into recession in 1991. Though the Federal Reserve intervened to lower interest rates, the supply of loans did not increase. Indeed, the spread between short-term interest rates (which banks had to pay on deposits) and longterm interest rates increased. Given that long-term government bonds were treated as safe assets (i.e. with no recognition that part of the higher return on long-term bonds was a risk premium associated with the risk of a fall in the price of the bond), given that many banks were worried about satisfying capital requirements, given that the experiences of the 1980s (and the regulators' responses to those experiences) had made them more risk averse, and 
Figure 8

Effect of Loosening Monetary Policy

Looser monetary policy induces banks to increase the supply of funds available at any interest rate. But if banks are extremely risk averse (say because they have had a large adverse shock to their net worth as a result of increases in non-performing loans), the shift in the loanable funds supply curve may be limited, so the change in the interest rate may be limited. Panel $\mathrm{B}$ shows that if there is credit rationing, interest rates charged may not change, even if the shift in the loanable funds curve is more marked. Panel C shows that if the demand for funds curve is highly inelastic, then, even if the interest rate changes, the amount of lending (and, correspondingly, the amount of investment) may increase little.

Panel A

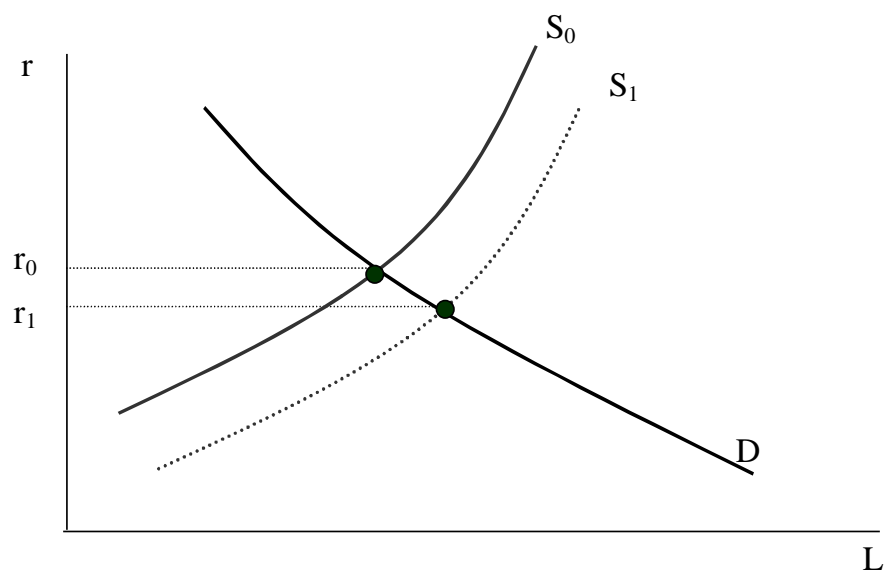

Panel B

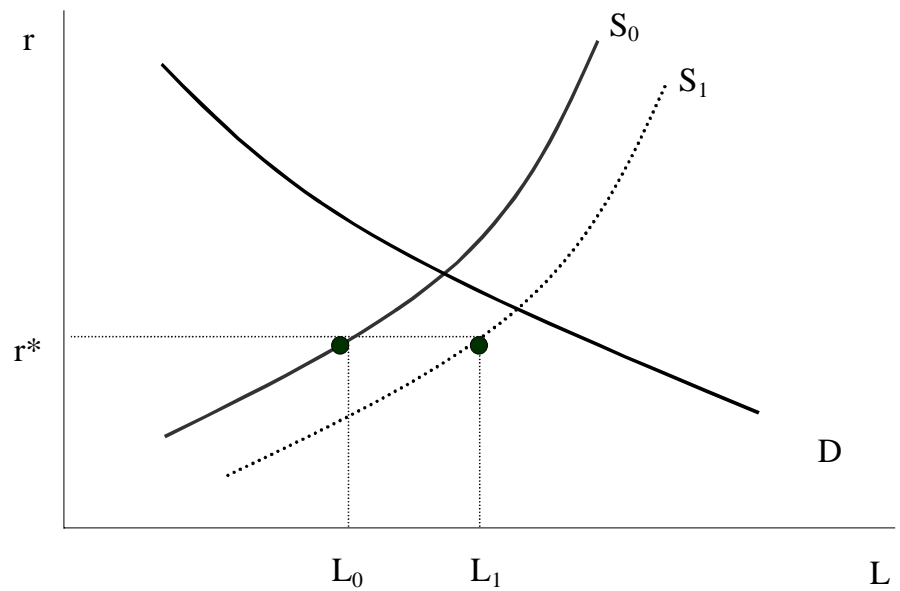

Panel C

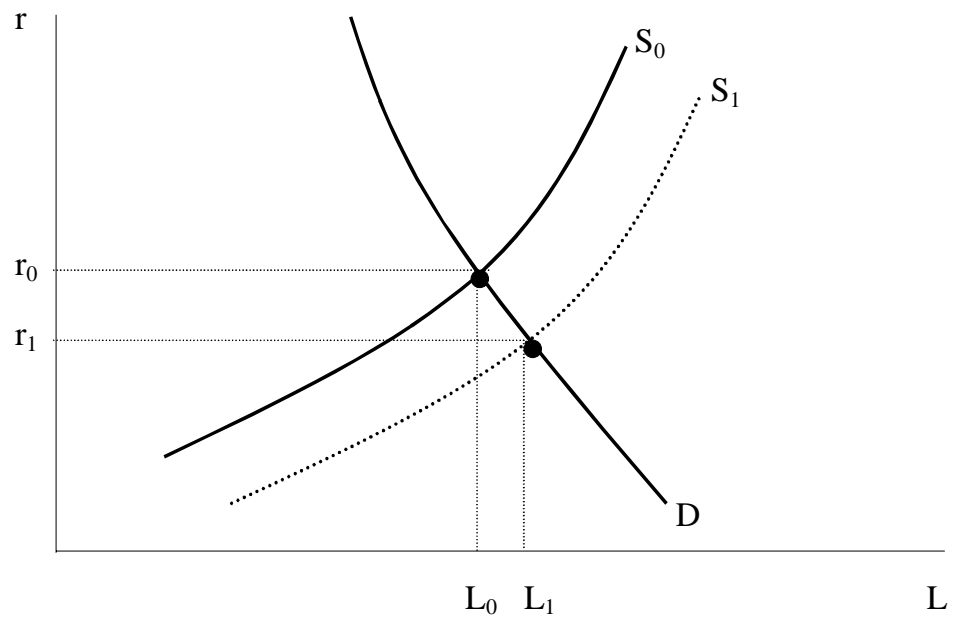


given that banks wanted to make it look as if they were more 'profitable', investing in long-term government bonds was viewed as preferable to lending (which given that the economy was entering a recession, looked particularly risky) or to investing in other instruments. The theory thus provides an explanation for a liquidity trap, but one which is markedly different from that discussed by Keynes (which, for good reason, has fallen out of favour). Monetary authorities have a hard time driving the relevant interest rate, that on loans, down. (The theory of the equity constrained firm, at the same time, can provide part of the explanation for the inelastic demand curve for investment, so that even were the monetary authorities successful in driving down the interest rate, investment might not be increased by much.)

The model has another important implication. Traditional monetary theory was based on a stable relationship between the money supply, income, and interest rates. While expectations about future economic prospects might have marked effects on the IS curve, the LM curve was stable. If the economy was in a recession, it was easy for the monetary authorities to figure out by how much they should lower interest rates to restore the economy to full employment, provided they knew the interest elasticity of investment. They calculated by how much investment would have to increase to restore the economy to full employment, and given the interest elasticity, they could easily calculate the required lowering of interest rates. From here, it was easy to determine the requisite increase in the money supply. But as the experience in 1991 showed, even marked lowering of interest rates did not have the anticipated effect in restoring the economy to full employment. While there is some argument about the reason for this, it is clear that the amount of funds lent did not increase in the way predicted. Clearly, the relationship between money and credit had changed; and it is credit, not money, which matters for economic activity. One possible explanation for the changed relationship is that noted above: banks were reluctant to lend; they rationed credit, so that investment did not increase in the way that it would have, given the fall in interest rates, had there not been credit rationing. ${ }^{17}$

\section{INTERNATIONAL DIMENSIONS}

The discussion so far has focused on closed economies. There are additional interest-rate puzzles in open economies-particularly associated with interest-rate parity. The difference between the interest rates in two different countries should be equal to the (risk-adjusted) expected depreciation; but it is hard to reconcile the data with such an interest arbitrage relationship (see, for example, Frankel, 1992). To be sure, since what matters is expectations of depreciation, and there is a further adjustment for 'risk', there are tautological ways in which one can ensure the relationship is satisfied (risk aversion or risk perceptions changed in the required ways), but these are unconvincing.

I do not propose here to resolve that dilemma. But there is another policy dilemma that has played an important role in recent policy debates. According to the standard theory, if a country increases the interest rate it pays, given expectations about depreciation of the currency, and given risk perceptions, then it becomes relatively more attractive to hold funds in the country. There should be a flow of funds into the country. The flow of funds into the country should serve to strengthen the currency, i.e. lead to an appreciation. Given expectations about the future course of the country's economy, there is a new, higher equilibrium exchange rate. Thus, raising interest rates is the standard prescription for stabilizing a country's exchange rate.

In the East Asia crisis that began in July 1997, this standard prescription failed to arrest the decline in exchange rates, much to the consternation of the

\footnotetext{
${ }^{17}$ Of course, another possible explanation — put forth by those who do not believe that credit rationing played an important roleis that the elasticity of investment was smaller than anticipated; and that the spreads increased so that the decrease in lending rates was not as much as the decrease in T-bill rates. The increased spreads, in this view, are not due to the theory of banking put forward here, but rather to the increased riskiness of borrowers. But, presumably, the variable which is of concern to borrowers is not the 'nominal' interest rate, but the risk-adjusted interest rate, and the risk-adjusted interest rate should have gone down as the T-bill rate went down, and thus investment should have gone up. (Of course, if there are differences in opinion about the risk, so that lenders view there being greater risk than borrowers, then lenders view themselves as paying more than borrowers view themselves as receiving. An increase in this wedge, in the discrepancy in perceptions, will then lead to a decrease in borrowing (see Stiglitz, 1972).
} 
doctors who had prescribed it. ${ }^{18}$ To be sure, they were ready with explanations: the patient had not followed all the doctors' orders, and given that, it was not surprising that the medicine did not work. (Had they not made such strong predictions about what was supposed to have happened, they could have made another argument: but for the interventions, the exchange rate would have fallen even more.) All sides in the policy debate agreed that what was central were expectations. Those arguing for a higher interest rate argued that not only would there be a positive direct effect from the higher return to keeping funds in the country, but also that the fact the country was following the doctors' orders would restore confidence, i.e. presumably reduce the perception of risk. These predictions were not, however, based on a coherent model of the structure of the economy, e.g. based on rational expectations, or on a signalling equilibrium. ${ }^{19}$ By contrast, critics of the interest-rate policy argued that its advocates had failed to note first, that most of the debt was private-sector debt; second, that a critical variable determining the riskadjusted expected return on private-sector debt was the probability of bankruptcy; third, that concerns about bankruptcy were of first order-it was these concerns that had led banks to refuse to roll over the loans at any interest rate, ${ }^{20}$ fourth, that the probability of bankruptcy is endogenous; and fifth, that the policies being pursued were likely to increase that probability, possibly so much as to reduce the riskadjusted expected return. If that were the case, then raising interest rates would actually contribute to the weakening of the exchange rate, by encouraging capital to flow out of the country; and even if the probability of bankruptcy did not increase so much as to lower the risk-adjusted expected return, the increase in the risk-adjusted expected return would be much lower than the increase in the interest rate charged itself, so that the impact on the exchange rate would be much less than anticipated.
The adverse effects of raising interest rates in East Asia were particularly significant, since firms were very highly leveraged with short-term debt. In those circumstances, the huge increases in interest rates quickly eroded the net worth of firms, and pushed many firms into bankruptcies, with all the predicted adverse effects both on aggregate demand and on aggregate supply. As the number of nonperforming loans increased, the balance sheet of banks became even worse. That by itself would have shifted the supply curve of funds to the left. But given the initial weaknesses of the financial institutions, and given the magnitude of the increase in interest rates-so the number of non-performing loans became enormous - a number of banks became insolvent. In some countries, rather than being recapitalized, many banks were shut down. This contributed to the further contraction of the availability of funds-shifting the loanable funds curve further to the left. The weakening of firms meant, at the same time, that the demand for funds for investment also decreased; but the need for funds just for working capital increased. As the monetary authorities then attempted to ease, the damage had already been done: banks and firms had both been weakened to the point where (at least in some countries) even as government interest rates came down, the level of lending interest rates did not. But even had lending interest rates come down, the level of investment (and therefore the level of economic activity) that it would have generated was limited.

Interestingly, when we looked back over the historical experience-asking whether increasing interest rates had had the desired or predicted effect in countries facing crises - the answer seemed to be ambiguous. Sometimes it had, but just as frequently it had not (see Furman and Stiglitz, 1998; Kraay, 1998). On-going research is attempting to ascertain the circumstances under which increasing interest rates had the desired or predicted effects.

\footnotetext{
${ }^{18}$ There were other elements of the prescription that were supposed to reinforce the increase in exchange rates-large adjustments in fiscal policy and very large bail-outs.

${ }^{19}$ See Stiglitz (1999) for a more extensive discussion of these points. There, I point out that the standard signalling argumentthat high interest rates show that the monetary authorities have 'resolved' to address the underlying problems—may be turned on its head. In the case of the Latin American crisis, the monetary authorities did need to tighten, in order to address the underlying macroeconomic problems. In the case of East Asia, arguably there were no underlying macroeconomic problems. By using policies that were appropriate for a macroeconomic problem for addressing problems of a quite different nature, the central bank could have been interpreted as signalling its inability to address the relevant situation; the signalling effect thus could have been adverse.

${ }^{20}$ This suggests the importance of the credit-rationing model.
} 
Given this historical experience, it is perhaps not surprising that investors, seeing an increase in interestrates, do not automatically believe that exchange rates will increase; there is little rational basis for them to have confidence, at least in the strengthening of the exchange. On the other hand, there was a large body of literature showing that increases in interest rates - particularly of the magnitude in East Asia-would have adverse effects on aggregate demand. The implication was clear: if, as seemed to be the case, the countries of East Asia were in rough macroeconomic balance immediately before the crisis, then the large increases in interest rate would clearly suffice to push them into a major recession, even if nothing else had been going on. But in fact, the fall in the stock market and the decrease in the exchange rate had marked adverse wealth effects. In Thailand, the bursting of the real estate bubble shut down investment in that sector. Thus, even without the increase in interest rates, the economies were headed for a severe recession. To make matters even worse, the countries were urged to have a fiscal contraction. Remarkably, the First Deputy Manager of the IMF, Stanley Fischer, said that all he was asking of them was to have a balanced budget - not a structural balanced budget, but an actual balanced budget (see Fischer, 1997). Data on falling consumption (especially car purchases) quickly corroborated the predictions. But given that the economies were thus seen to be falling into severe recessions ordepressions, it is not surprising that rational investors would see a large increase in the probability of default, and it thus became less attractive to put money into the country-and more attractive for those in the country to take their money out. Given the known association between ethnic and political instability (especially in countries with a history of those instabilities) and economic downturns, it is also not surprising that investor confidence would be eroded on that account. The erosion of confidence in the economy can be explained without any reference to the patient not fulfilling all the doctors' orders, but rather simply, on the basis that the prescription-the high interest rates and the fiscal contraction-were exacerbating the economic decline.

The doctors had one more excuse. They claimed that had they not increased the interest rates, the exchange rates would have declined even more, and given the fact that the countries were net debtors, the adverse effects on the country's balance sheet would themselves have led to a decline; though they admit the adverse effect of the higher interest rate, the adverse effect of the larger decline in exchange rates would have been even greater, or at least so they argue - without any empirical evidence either about the imputed trade-offs between exchange rates and interest rates or of the effect of changes in either on aggregate economic activity. The argument, however, misses the details of the situation confronting each country, ignores the potential role of bankruptcy laws, and, most importantly, fails to take into account the bankruptcy effects upon which our discussion has centred. The adverse effects on firms' balance sheets-putting them into distress and at, or over, the verge of bankruptcy - meant, as noted, that there may not have been any trade-off. Raising interest rates exacerbated the decline in the exchange rates. By ignoring the effect on the bankruptcy probability, they in effect assumed that raising interest rates would make it more attractive for investors to put, or keep, their money in the country. Had bankruptcy laws been invoked, the magnitude of the redistributions to foreigners would have been limited; but, quite explicitly, even though the debt is private sector, one of the main objectives of the interventions (acting on behalf of, or seemingly in the interests of, the foreign creditors) was to prevent such non-repayments. And, at least in some of the cases, even if the failure to raise interest rates had led to slightly greater devaluations (a hypothesis for which, as I have said, there is little evidence), and even if more widespread use of bankruptcy laws had not been undertaken, the adverse effects on economic activity would have been limited, in at least some of the countries. Take Thailand, for instance, where the firms with major exposures were the real estate firms (and the financial institutions that had lent to them) and exporters. The former were already 'dead' as a result of the crash of the real estate boom; hence, further devaluations would have had little incremental effect on the level of economic activity. And the latter were, for the most part, essentially covered: as exporters they more than gained what they lost in the real value of their indebtedness in terms of local currency. ${ }^{21}$

\footnotetext{
${ }^{21}$ To be sure, there were some firms that had gambled, and had excessive foreign-exchange exposure. But there is a fundamental moral-hazard issue: should government policy be more directed at bailing out or protecting firms that have engaged in excessive risk taking (these firms should have purchased cover for their exposure), or should it put at risk well-behaved firms, that had simply borrowed amounts that were, or would have been, fully prudential, had interest rates not been increased to exorbitant levels?
} 


\section{ALTERNATIVE MODELS}

Before concluding, I should say a word about some alternative models. Tobin's generalized portfolio approach (Tobin, 1958) has interest rates (and the returns on all other assets, including equity) determined by a generalized set of demand and supply curves for assets. The approach focuses on the demand curves for different assets, with the monetary authorities, through open market operations, essentially changing the relative supply of two of the assets: money and T-bills. Generalizations of Barro's theorem on Ricardian equivalence (see Stiglitz, 1981, 1988a) suggest that such a switch should have relatively little effect (especially in an era when money bears essentially the same interest rate as Tbills) through household portfolios. But banks- the institutions through which lending occurs-are affected, and it is upon this channel of monetary policy that we have focused. Similarly, while the interdependence of demand curves in the portfolio approach does imply that such changes will affect the price of equities, we have noted that relatively little of the funds for new investment is raised in the equity market; and Tobin's q-model, focusing on the price of equity as a determinant of investment, has not fared well (see, for example, Abel and Blanchard, 1986). Monetary policy can have large impacts through the banking system on the supply of loanable funds, and hence on market rates of interest. Changes in monetary stances may affect the short-run risks facing investors in various instruments, and in the short run, these risk perceptions may play a large role in determining relative prices and returns. Still, the portfolio approach, in conjunction with a 'banking' model, may help provide some of the explanation of the movements in short-term interest rates during at least some periods. For instance, one hypothesis concerning the high real interest rates during the 1980s in the United States was that the negative or low net worth savings and loans institutions gambled on resurrection, offering depositors high government guaranteed interest rates to attract funds; these deposits, since they were government guaranteed, competed with T-bills, and T-bill rates accordingly had to increase to compete. ${ }^{22}$

\section{CONCLUDING REMARKS}

The interest rate is a key variable in most macroeconomic models; yet its movements, both in the short term and the long, seem hard to account for fully, particularly in the simple models which have long been fashionable. We have argued that the insights provided by the portfolio balance theory, combined with the perspectives provided by recent advances in our understanding of imperfections in capital markets, provide the framework of a theory which goes a long way towards providing an explanation of at least several of the central phenomena. Several concepts have played pivotal roles: imperfections of information, and the risks of default (which are endogenous) with their consequences, including credit and equity rationing; the resulting capitalmarket imperfections leading in turn to riskaverse behaviour of firms and banks; the fact that as a result, firm and bank behaviour are affected by balance-sheet and cash-flow variables; and the central role played by banks in credit markets. All of these together provide a far richer model of the capital market, one that cannot be well summarized in a money demand equation. More importantly, policy based on that simple model is likely to-and has in the pastgone seriously awry.

\footnotetext{
${ }^{22}$ An explanation sometimes put forward for the negative returns in the 1970s is that the unexpected increase in inflation meant that realized real returns were lower than expected real returns. This explanation, however, is not entirely satisfactory; while the oil price increase was a shock, it would have seemed that inflation expectations should have adapted quickly enough so that there should not have been negative real returns throughout the rest of the decade. Moreover, the increased perception of inflationary risk should have made these instruments less attractive than, say, equities, so that the real return should have even increased.
} 


\section{REFERENCES}

Abel, A. B., and Blanchard, O. J. (1986), 'The Present Value of Profits and Cyclical Movements in Investments', Econometrica, 54, 249-74.

Asquith, P., and Mullins, D. W. (1986a), 'Equity Issues and Stock Price Dilution', Journal of Financial Economics, 13, 296-320.

- _ - (1986b), 'Equity Issues and Offering Dilutions', Journal of Financial Economics, 15, 61-89.

Bernanke, B., and Gertler, M. (1989), 'Agency Costs, Net Worth, and Business Fluctuations', American Economic Review, 79(1), 14-31.

Calomiris, C. W., Hubbard, R. G., and Stock, J. H. (1986), 'The Farm Debt Crisis and Public Policy', Brookings Papers on Economic Activity, 2, 441-79.

— _ _ - (1987), 'Price Flexibility, Credit Availability and Economic Fluctuations: Evidence from the US: 1879_ 1914', Northwestern University.

Chamberlain, E. (1933), The Theory of Monopolistic Competition, Cambridge, MA, Harvard University Press.

Devereux, M., and Schiantarelli, F. (1990), 'Investment, Financial Factors, and Cash Flow: Evidence from the UK Panel Data', in R. G. Hubbard(ed.), Information, Capital Markets, and Investment, Chicago, IL, University of Chicago Press.

Fazzari, S., Hubbard, G., and Peterson, B. (1988), 'Financing Constraints and Corporate Investment', Brookings Papers on Economic Activity, 1, 141-206.

Fischer, S. (1997), 'IMF-The Right Stuff', Financial Times, 17 December.

Frankel, J. (1992), 'Measuring International Capital Mobility: A Review', American Economic Review, Papers and Proceedings, 82(2), 197-202.

Furman, J., and Stiglitz, J. E. (1998), 'Economic Crises: Evidence and Insights from East Asia', Brookings Papers on Economic Activity, 1-135.

Galeotti, M., Jaramillo, F., and Schiantarelli, F. (1990), 'Investment Decisions and the Role of Debt, Liquid Assets and Cash Flow: Evidence from Italian Panel Data', Boston University Working Paper, March.

Gilchrist, S. (1989), 'An Empirical Analysis of Corporate Investment and Financing Hierarchies Using Firm Level Panel Data', University of Wisconsin, mimeo.

Greenwald, B. C., and Stiglitz, J. E. (1987), 'Imperfect Information, Credit Markets and Unemployment', European Economic Review, 31, 444-56.

- _ - (1990a), 'Macroeconomic Models with Equity and Credit Rationing', in R. G. Hubbard (ed.), Asymmetric Information, Corporate Finance, and Investment, Chicago, IL, University of Chicago Press, 15-42.

- _ (1990b), 'Asymmetric Information and the New Theory of the Firm: Financial Constraints and Risk Behavior', American Economic Review, 80(2), 160-5.

- _ (1991a), 'Towards a Reformulation of Monetary Theory: Competitive Banking', Economic and Social Review, 23(1), 1-34.

- _ (1991b), 'Examining Alternative Macroeconomic Theories', in E. Phelps (ed.), Recent Developments in Macroeconomics, Edward Elgar, 335-88.

- _ (1993), 'Financial Market Imperfections and Business Cycles', Quarterly Journal of Economics, 108(1), 77-114.

- _ (1995), 'Labor Market Adjustments and the Persistence of Unemployment', American Economic Review, $\mathbf{8 5}(2), 219-25$.

- - Weis, A. (1984), 'Informational Imperfections in the Capital Markets and Macroeconomic Fluctuations', American Economic Review, 74(2), 194-9.

Hellman, T., and Stiglitz, J. E. (2000), 'Credit and Equity Rationing in Markets with Adverse Selection', European Economic Review, forthcoming.

Hoshi, T., Kashyap, A., and Scharfstein, D. (1988), 'Corporate Structure and Investment: Evidence from Japanese Panel Data', MIT Sloan School of Management Working Paper, 2071-88.

- _ - (1991), 'Corporate Structure, Liquidity and Investments: Evidence from Japanese Industrial Groups', Quarterly Journal of Economics, 106, 33-59.

Hubbard, R. G., and Kashyap, A. (1989), 'Internal New Worth and the Investment Process: An Application of US Agriculture, 1910-1987', mimeo.

Jaffee, D., and Stiglitz, J. E. (1990), 'Credit Rationing', in B. Friedman and F. Hahn (eds.), Handbook of Monetary Economics, Amsterdam, Elsevier Science Publishers, 837-88.

Kane,E.J.(1989), 'How Incentive-Incompatible Deposit-Insurance Funds Fail', National Bureau of Economic Research Working Paper 2836, February, 32. 
Keynes, J. M. (1936), The General Theory of Employment, Interest and Money, London, Macmillan.

Kraay, A. (1998), 'Do High Interest Rates Defend Currencies Against Speculative Attacks', unpublished paper, World Bank, August.

MaCurdy, T. E., and Shoven, J. B. (1992a), 'Stocks, Bonds, and Pension Wealth', in D. A. Wise (ed.), Topics in the Economics of Aging, National Bureau of Economic Research Project Report, Chicago, IL, University of Chicago Press, 61-75.

- _ (1992b), 'Accumulating Pension Wealth with Stocks and Bonds', CEPR/Stanford University, unpublished mimeo.

- _ - (1992c), 'Do Long Term Bonds Pay Off?', CEPR/Stanford University, unpublished mimeo.

Mayer, C. (1990), 'Financial Systems, Corporate Finance, and Economic Development', in R. G. Hubbard (ed.), Asymmetric Information, Corporate Finance, and Investment, Chicago, IL, University of Chicago Press.

Modigliani, F., and Miller, M. H. (1958), 'The Cost of Capital, Corporation Finance and the Theory of Investment', American Economic Review, 48(3), 261-97.

Myers, S.C., and Majluf, N. S. (1994), 'Corporate Financing and Investment Decisions when Firms Have Information that Investors do not Have', in M. J. Brennan (ed.), The Theory of Corporate Finance, Vol. 1, Elgar Reference Collection, International Library of Critical Writings in Financial Economics, No. 1.

Robertson, D. H. (1936), 'Some Notes on Mr Keynes' General Theory of Employment', Quarterly Journal of Economics, 51(1), 168-91.

Rodriguez, A., Stiglitz, J. E., and Weiss, A. (1992), 'Adverse Selection, Credit Rationing and Central Bank Policy', Stanford University Working Paper.

Stiglitz, J. E. (1972), 'Some Aspects of the Pure Theory of Corporate Finance: Bankruptcies and Take-Overs', Bell Journal of Economics, 3(2), 458-82.

- (1973), 'Taxation, Corporate Financial Policy and the Cost of Capital', Journal of Public Economics, 2(February), 1-34. (Subsequently published in A. Atkinson (ed.) (1991), Modern Public Finance, Vol. 1, International Library of Critical Writings in Economics, No. 15, Elgar, 96-129.)

- (1974), 'On the Irrelevance of Corporate Financial Policy', American Economic Review, 64(6), 851-66.

- (1981), 'On the Almost Neutrality of Inflation: Notes on Taxation and the Welfare Costs of Inflation', in M. J. Flanders and A. Razin (eds), Development in an Inflationary World, New York, NY, Academic Press, 419-57.

- (1982a), 'Ownership, Control and Efficient Markets: Some Paradoxes in the Theory of Capital Markets', in K. D. Boyer and W. G. Shepherd (eds), Economic Regulation: Essays in Honor of James R. Nelson, Michigan State University Press, 311-41.

- (1982b) 'Information and Capital Markets', in W. F. Sharpe and C. Cootner (eds), Financial Economics: Essays in Honor of Paul Cootner, Englewood Cliffs, NJ, Prentice Hall, 118-58.

- (1983a), 'On the Relevance or Irrelevance of Public Financial Policy: Indexation, Price Rigidities and Optimal Monetary Policy', in R. Dornbusch and M. Simonsen (eds), Inflation, Debt and Indexation, Cambridge, MA, MIT Press, 183-222.

- (1983b), 'Some Aspects of the Taxation of Capital Gains', Journal of Public Economics, 21(July), 257-94.

- (1988a), 'On the Relevance or Irrelevance of Public Financial Policy', in The Economics of Public Debt, Macmillan Press, 4-76.

- $\quad$ (1988b), 'Money, Credit, and Business Fluctuations', Economic Record, 64(187), 62-72.

- (1989), 'Mutual Funds, Capital Structure, and Economic Efficiency', in S. Bhattacharya and G. Constantinides (eds), Theory of Valuation-Frontiers of Modern Financial Theory, Vol. 1, Totowa, NJ, Rowman and Littlefield, 342-56.

- (1992), 'Capital Markets and Economic Fluctuations in Capitalist Economies', European Economic Review, 36, 269-306.

- (1995), 'Interest Rate Puzzles, Competitive Theory and Capital Constraints', in J.-P. Fitoussi (ed.), Economics in a Changing World, Proceedings of the Tenth World Congress of the International Economic Association, Moscow, Vol. 5, Economic Growth and Capital and Labour Markets, IEA Conference Volume No. 111, New York, St Martin's Press, 145-75.

- (1999), 'Whither Reform? Ten Years of the Transition', Proceedings of the 1999 Annual Bank Conference on Development Economics, Washington, DC, The World Bank.

- Weiss, A. (1981), 'Credit Rationing in Markets with Imperfect Information', American Economic Review, 71(3).

- _ (1992), 'Asymmetric Information in Credit Markets and Its Implications for Macroeconomics', Oxford Economic Papers, 44(4), 694-724.

Tobin, J. (1958), 'Liquidity Preference and Behaviour Toward Risk', Review of Economic Studies, 25, 65-86. 